\title{
VYRESNIO AMŽIAUS LIETUVOS GYVENTOJŲ GEROVĖS IR SVEIKATOS SĄSAJOS
}

\author{
Antanas Kairys, Albinas Bagdonas, Olga Zamalijeva \\ Vilniaus universiteto Filosofijos fakulteto Specialiosios psichologijos laboratorija
}

Raktažodžiai: sveikata, gerovè, gyvenimo kokybė, sisteminè analizè.

\section{Santrauka}

Tiek empiriniai tyrimai, tiek teorinès prielaidos rodo, kad gerove yra sudètingas, daugiamatis konstruktas. Tyrimais nustatyta, kad su gerove siejasi daugybe veiksnių, o tarp jų ypač svarbūs yra ir sveikatos veiksniai. Gerovès ir sveikatos tarpusavio ryšių tyrimą apsunkina tai, kad egzistuoja daug kitų kintamujų, kurie gali keisti ryšio pobūdị. Iki šiol nèra aiškaus atsakymo, kaip kinta vyresnio amžiaus žmonių gerovė jų senèjimo eigoje, koks sveikatos veiksnių vaidmuo šiame kitime. Dar vienas svarbus tyrimų faktas - gerovè ir sąsajos tarp sveikatos ir gerovès gali priklausyti nuo šalies ar kultūros, todèl yra svarbu žinoti, kokie vyresnio amžiaus asmenų sveikatos ir gerovès sąsajų tyrimai atlikti Lietuvoje. Todèl tyrimo tikslas - naudojant sisteminès analizès metodą, išanalizuoti Lietuvoje atliktus vyresnio amžiaus asmenų sveikatos ir gerovès sąsajų tyrimus. Straipsnių paieška atlikta duomenų bazėse PsychInfo, Academic Search Complete, MEDLINE, SocINDEX with Full Text, ERIC, Science direct ir Lituanistika. Iš viso rasti 897 straipsniai. Remiantis pavadinimu, atrinkti 274 straipsniai, remiantis santrauka ir visu tekstu, galutinai analizeje liko 16 straipsnių. Analizuoti tyrimai rodo, kad sirgimas viena ar kita liga (věžiu, Parkinsono liga, išemine širdies liga, reumatoidiniu artritu, kepenų ciroze ar šlapimo nelaikymu) yra susijęs su žemesne gerove. Taip pat yra įrodymų, kad ligai progresuojant, gerovė prastejja. Prastesnè gerové siejasi ir su psichikos sveikatos problemomis. Analizuoti tyrimai pasižymi metodologiniais trūkumais - tyrimų dalyvių imčių reprezentatyvumo stoka, ribotais gerovès tyrimo instrumentais bei dažniausiai ribotu daugiamatès statistinès analizès taikymu. Atlikta sisteminè analizè leidžia teigti, kad Lietuvoje trūksta longitudinių, gyventojų struktūrą reprezentuojančių, lyginančių skirtingas sveikatos būkles skirtingomis gyvenimo aplinkybèmis, taikančių šiuolaikinius daugiamatès statistikos metodus, gerovès tyrimų.

\section{Ivadas}

Domejimasis savijauta, gerove toks pat senas, kaip ir žmogaus savivoka - gebejjimas suvokti ir reflektuoti save. Tai ką šiuo metu vadiname gerove, gyvenimo kokybe, gera savijauta ar tiesiog laimès jausmu - domino jau Antikos filosofus, tarp jų ir Aristoteli [1]. Taigi, natūralu, kad ir dabartiniais laikais žmogaus gerové - vienas esminių ne tik mokslinių tyrimo objektų, bet politinių judejjimų ideologijų tikslų. Gerove domisi daugelio sričiu - medicinos, psichologijos, politikos, sociologijos, ekonomikos ir kt. - mokslininkai. Tokiame margame tyrimo lauke buvo sukurta visa eilè sąvoku - gerovè (subjektyvi, psichologinè, socialinè), gyvenimo kokybė, pasitenkinimas gyvenimu ir kt. Vienos jų, - psichologinė ar subjektyvi gerovè - labiau pabrèžia subjektyvų potyrị, kitos dažnai apima ir objektyvų komponentą. Situaciją sunkina ir tai, kad kartais skirtingos sąvokos, pavyzdžiui, gerovè ir gyvenimo kokybe், naudojamos kaip sinonimai [2], kitais atvejais įžvelgiamas skirtumas tarp jų (pavyzdžiui, [3]). Yra ne vienas bandymas siūlyti galima skètinị terminą. Pavyzdžiui, S. Krutulienè [4] skètiniu terminu siūlo gyvenimo kokybės sąvoką. A. Bagdonas ir bendraautoriai (2013) skètiniu terminu siūlo psichologinès gerovès sąvoką, teigdami, kad ji apima daugelị geros savijautos aspektų. Mes linktume pritarti gerovès sąvokos naudojimui, tačiau manytume, kad norėdami aprèpti ir objektyvesnę gyvenimo kokybę ar tokius gyvenimo kokybės aspektus, kaip su sveikata susijusi gyvenimo kokybė, turètume atsisakyti žodžio „psichologiné“, todèl šiame straipsnyje sąvoką ,gerovè“ naudosime kaip skètinę visų gerą asmens savijautą reiškiančių aspektų (pirmiausia gyvenimo kokybès, psichologinès ir subjektyvios gerovès, pasitenkinimo gyvenimu) sąvoką. Gerovès sąvoka kaip objektyvios gyvenimo kokybès sinonimas (materialinès, teisinès, socialinio teisingumo ir solidarumo prasmèmis) naudojama socialinès ekonomikos ir politikos srityje (pavyzdžiui, žmogaus gerové, gerovès valstybè). 
Tiek empiriniai tyrimai $[5,6]$, tiek teorinès prielaidos [4] rodo, kad gerovè yra sudètingas, daugiamatis arba daugiakomponentis konstruktas. Tyrimais taipogi nustatyta, kad gerovè yra multideterminuotas konstruktas, kitaip tariant, gerovę, tikètina, nulemia daugelis priežasčiu - genetiškai nulemtos asmens smegenų ir bazinių psichinių funkcijų specifinès organizacijos, susiformavę asmenybès bruožai, ekonominès ir teisinès aplinkybès (pavyzdžiui, pajamos, darbinis statusas, visuomenèje egzistuojančios žmogaus teisès), socialinès (pavyzdžiui, socialinis tinklas) ir kt. [5, 7]. Tarp išvardintų ir daugybès kitu gerovès veiksniu labai svarbūs yra ir sveikatos veiksniai. Apibendrinant, praktiškai visuose tyrimuose, i kuriuos įtraukti ir sveikatos kintamieji $[5,8,9]$, nustatomos sąsajos tarp gerovès ir sveikatos kintamujų (pavyzdžiui, sirgimo įvairiomis ligomis, ligos eigos ar gydymo būdo, bendros sveikatos būklès, subjektyvaus sveikatos vertinimo ir t.t.). Paprastai ryšiai būna stipresni, jei sveikatos veiksniai ir gerovė vertinami subjektyviai [5]. Diskutuojama ir apie ryšių krypti. Tęstiniai tyrimai taip pat rodo, kad sveikata yra gerovès veiksnys: gera sveikata didina pasitenkinimą tiek gyvenimu apskritai, tiek atskirais jo aspektais (pavyzdžiui, santykiais su artimaisiais, teigiamomis emocijomis) [10]. Tačiau manoma, kad ryšiai gali būti ir abipusiai, tai yra laimès jausmas gali stiprinti ne tik subjektyviai suvokiamą, bet ir objektyvią sveikatą, t. y. teigiamai veikti žmogaus kūniškaji funkcionavimą [11].

Gerovės ir sveikatos tarpusavio ryšiu tyrimą dar labiau apsunkina tai, kad egzistuoja amžiaus ir kultūrinè specifika. Tarp įvairių amžiaus tarpsnių didelio dèmesio sulaukia vyresnio amžiaus žmonių gerovès ir sveikatos ryšiai. Žinia, žmogaus gyvenimo eigoje, ypač senejjant, vis dažnesniu palydovu tampa sveikatos blogèjimas. Beveik du trečdaliai suaugusiujų serga bent viena lètine liga, ties 50 gyvenimo metais beveik pusė asmenų serga bent dviem lètinèmis ligomis, o ketvirtadalis - bent trimis [12]. Tačiau iki šiol nėra aiškaus atsakymo, kaip kinta vyresnio amžiaus žmonių gerovė jų senëjimo eigoje, koks sveikatos veiksnių vaidmuo šiame kitime. Subjektyviai vertinama gerovè, kaip dažnai atranda tyrimai, su amžiumi kinta $\mathrm{U}$ raidès pavidalu, o žemiausias gerovès taškas pasiekiamas vidury penkiasdešimtujų metų [5, 7], nors yra ir kitokių kitimo trajektoriju $[8,13]$. Randama ir ịrodymu, kad kontroliuojant kitus kintamuosius (pavyzdžiui, sveikatos), gerovès prastejimo nebestebima [9]. Visi šie tyrimai tik kelia papildomų klausimų ir verčia toliau ieškoti atsa- kymų, kaip kinta vyresnio amžiaus asmenų gerovė, kaip ji siejasi su sveikata.

Dar vienas svarbus tyrimų faktas - gerovè ir sąsajos tarp sveikatos ir gerovès gali priklausyti nuo šalies ar kultūros. Tarpkultūriniai tyrimai atranda, kad U formos gerovès kitimas labiau būdingas Vakarų išsivysčiusioms šalims, tuo tarpu daugelyje kitų (pavyzdžiui, besivystančių Lotynų Amerikos ar Afrikos) šalių nustatomas nuoseklus gerovès blogèjimas [7]. Kiti tyrimai rodo, kad gerovès ir kitų kintamujų, pavyzdžiui, socialinio tinklo sąsajos gali priklausyti nuo geografinio regiono ir kultūros [14]. Lyginamieji Europos valstybiu tyrimai atskleidžia ženklią sveikatos ir gerovès nelygybę tarp šalių ir rodo, kad ji gali sietis su socioekonominiais bei sveikatos apsaugos sistemos ypatumais [15]. Tai reiškia, kad tyrimų rezultatų, atliktų kitose kultūrose ir esant kitokiai sveikatos apsaugos sistemai, tiesiogiai Lietuvos populiacijai taikyti negalime.

Atsižvelgiant $\mathfrak{i}$ tai, kas dèstyta pirmiau, kyla klausimas - ką mes žinome ir ką dar turètume sužinoti apie vyresnio amžiaus asmenų sveikatą ir gerovę Lietuvoje? Kokie yra metodologiniai atliktų tyrimų ribotumai?

Šio tyrimo tikslas - naudojant sisteminès analizès metodą, išanalizuoti Lietuvoje atliktus vyresnio amžiaus asmenų sveikatos ir gerovės sąsajų tyrimus.

\section{Tyrimo medžiaga ir metodai}

Straipsnių paieška atlikta duomenų bazėse PsychInfo, Academic Search Complete, MEDLINE, SocINDEX with Full Text, ERIC, Science direct ir Lituanistika. Paieškos žodžiai ir užklausos pavyzdys pateikti 1 lentelèje. Visose bazèse paieška atlikta ir lietuvių, ir anglų kalbomis. Paieška vykdyta 2017 m. kovo ir balandžio mėnesiais. Straipsnių publikavimo data neribota. Siekiant išplèsti paieškos lauką, rankiniu būdu peržiūrèti žurnalų "Gerontologija", "Psicho-

1 lentelè. Straipsnių paieškos raktažodžiai ir užklausos pavyzdys

Pastaba: * - bet kokia galūné. Konkretus naudotas simbolis priklausé nuo konkrečios bazès.

\begin{tabular}{|c|c|c|c|c|}
\hline \multirow[b]{3}{*}{$\begin{array}{l}\text { Rakta- } \\
\text { žodžiai }\end{array}$} & \multicolumn{4}{|c|}{ Sritis } \\
\hline & Gerovè & Šalis & Sveikata & Amžius \\
\hline & $\begin{array}{l}\text { Angliškai: well-being, well- } \\
\text { being, well being, quality of life, } \\
\text { life satisfaction } \\
\text { Lietuviškai: gerov*, gyvenimo } \\
\text { kokyb*, pasitenkinim* gyven- } \\
\text { imu }\end{array}$ & $\begin{array}{l}\text { Angliškai: } \\
\text { Lithuania } \\
\text { Lietuviškai: } \\
\text { nenaudota }\end{array}$ & $\begin{array}{l}\text { Angliškai: } \\
\text { health } \\
\text { Lietuviš- } \\
\text { kai: svei- } \\
\text { kat* }\end{array}$ & $\begin{array}{l}\text { Angliškai: } \\
\text { Elderly, old* } \\
\text { age, old* adults, } \\
\text { aging, retir*, } \\
\text { preretir*. } \\
\text { Lietuviškai: } \\
\text { senat*, vyresn* } \\
\text { amž*, pens*, } \\
\text { senej* }\end{array}$ \\
\hline $\begin{array}{l}\text { Užklau- } \\
\text { sos pa- } \\
\text { vyzdys }\end{array}$ & \multicolumn{4}{|c|}{$\begin{array}{l}\text { (well-being OR wellbeing OR well being) AND health AND Lithuania AND } \\
\text { (Elderly OR (old* age) OR (old* adults) OR aging OR retir* OR preretir*) }\end{array}$} \\
\hline
\end{tabular}


logija" bei "Tarptautinis psichologijos žurnalas: biopsichologinis požiūris" archyvai.

\section{Straipsnių įtraukimo kriterijai:}

1. Atliktas empirinis kiekybinis tyrimas, tyrimo dalyviai - žmonès. Neįtraukiami kokybiniai tyrimai, taip pat tyrimai, kurie analizuoja makroekonominius ar kitus rodiklius.

2. Tiriami vyresnio amžiaus $(50+)$ žmonès:

a) tiriami tik vyresnio amžiaus žmonès;

b) bendros populiacijos tyrime atskirai atlikta vyresnio amžiaus žmonių grupès analizė;

c) bendras imties amžiaus vidurkis daugiau kaip 50 metų.

3. Vienokiu ar kitokiu būdu tiriama gerové, gyvenimo kokybė ar pasitenkinimas gyvenimu.

4. Tirti vienokie ar kitokie fizinès ar psichikos sveikatos kintamieji ir atlikta jų sąsajų su gerove analizè.

5. İtraukiami straipsniai, kuriuose analizuojamos specifinès ligos.

6. Kadangi iš esmès analizè skirta priešpensinio ir pensinio amžiaus gerovès ir sveikatos sąsajų nustatymui, atmesti visi straipsniai apie specifines dirbančiujų grupes.

7. Itraukti tarptautinius palyginimus pristatantys straipsniai, jei juose atskirai aptariama Lietuva.

Tyrimų atranka schematiškai pavaizduota 1 pav. Iš viso rasti 897 straipsniai. Pirmiausia pagal itraukimo kriterijus buvo peržiūrimi visų rastų straipsnių pavadinimai. Remiantis pavadinimu, atrinkti 274 straipsniai. Vèliau, pašalinius dublikatus, buvo skaitoma straipsnio santrauka ir, jei reikia, viso teksto straipsnis. Remiantis santrauka ir visu tekstu, galutinai analizèje liko 16 straipsnių.

Duomenų surinkimas. Atrinkti straipsniai buvo analizuojami pagal iš anksto sudarytą schemą. Buvo fiksuojami imties tūris, tyrimo dalyvių amžius, imties tipas, tyrimo dalyvių atrankos principas, gerovès tyrimo būdas, fizinès sveikatos veiksniai, psichikos sveikatos veiksniai, ar taikyta daugiamatė statistika, esminiai rezultatai.

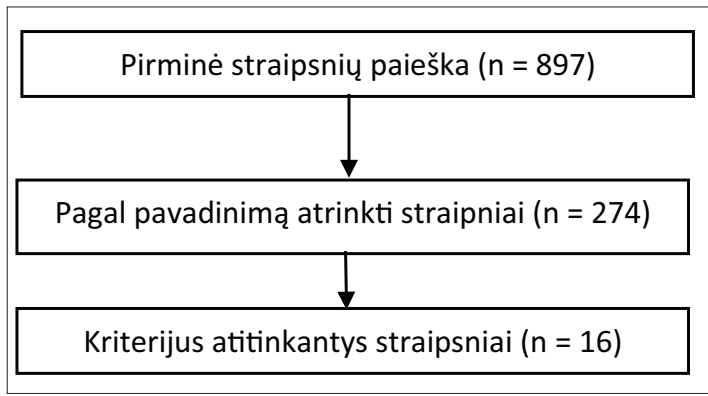

1 pav. Straipsnių atrankos schema

\section{Rezultatai}

Atlikus straipsnių atranką, iš viso rasta 16 visus atrankos kriterijus atitinkančių straipsnių. Analizuotų straipsnių parametrų santrauka pateikta 2 lentelèje. Straipsniai buvo publikuoti 2005 - 2016 metais. Ankstesnių metų straipsniai i atranką galejo nepatekti, nes ne visi žurnalai tuo metu jau buvo skaitmenizuoti ir ịtraukti ị duomenų bazes, tuo tarpu naujausi tyrimai dar gali būti nepublikuoti, recenzuojami.

Analizuojant tyrimo imties tūrị, nustatyta, kad jis buvo nuo 62 iki 6947 asmenų $(M=1158,4 ; \mathrm{Me}=343,5)$. Dviejų tyrimų (12,5\%) imtis buvo mažesnè nei 100 , penkių (31,3\%) mažesnè nei 200 , aštuonių (50\%) - mažesnè nei 300 asmenų.

Dvylika tyrimu (75\%) buvo įtraukti, nes tyrimo dalyvių amžiaus vidurkis arba tikètinas amžiaus vidurkis buvo didesnis nei 50 metų. Tik ketvirtadalis tyrimų įtraukè būtent tik $50+$ metu žmones.

Daugiausia $(\mathrm{n}=9 ; 56,3 \%)$ atrinktų tyrimų įtraukè asmenis, pasižyminčius specifiniais sveikatos sutrikimais. Dviejuose tyrimuose (12,5\%) dalyvavo respondentai, kurie kreipèsi ị gydymo įstaigą, penkiuose tyrimuose $(31,3 \%)$ dalyvavo bendros populiacijos respondentai. Iš šiu tyrimų keturi (25\%) buvo longitudiniai.

Kalbant apie analizuotuose straipsniuose pristatomų tyrimų imties sudarymo principą, didžioji dalis tyrimų -9 $(56,3 \%)$ tyrè vienos ar kelių ịstaigų pacientus ar besikreipiančius $i$ jas asmenis. Penkiais atvejais $(31,3 \%)$ buvo taikoma atsitiktinè atranka, dažniausiai iš vieno regiono. Po vieną tyrimą (po 6,3\%) surinko patogiają imti arba derino atranką iš institucijų ir atsitiktinę atranką.

Gerovei tirti analizuotuose straipsniuose iš viso panaudoti 11 skirtingų instrumentų, dar trys tyrimai gerovę vertino vienu klausimu. Didžioji dalis klausimynų (I-QOL, FACT-G ir FACT-An, OAB-q, EORTC QLQ-C30 ir kt.) buvo skirti tirti su specifine liga, sutrikimu ar gydymo eiga susijusią gyvenimo kokybę.

Keturiolikoje iš analizuotų straipsnių $(87,5 \%)$ buvo itraukti fizinès sveikatos veiksniai. Dažniausiai - trylikoje straipsnių, buvo analizuojami ligos eiga, simptomai, stadija, gydymo ypatumai ir panašūs su sirgimu konkrečia liga ar kažkokios medicininès būklès turèjimu susiję veiksniai. Šių tyrimų rezultatai atskleidžia, kad didžioji žmonių dalis mano, kad sveikata stipriai veikia jų gyvenimo kokybę [23]. Sirgimas viena ar kita liga siejasi su gyvenimo kokybès prastèjimu. Tai nustatyta kepenų cirozès [19], šlapimo nelaikymo $[18,22,25]$ atvejais. Taip pat atrandama, kad ligai progresuojant, gerovè taip pat blogèja. Šis blogèjimas nustatomas pakartotinių tyrimų metu, tiriant sergančiuosius Parkinsono liga [17], sergančius reumatoidiniu artritu [21], moteris, besigydančias krūties vèžị skirtingais būdais $[16,20]$. Gerovès blogejjimas aptinkamas ir prostatos vèžiui progresuojant [26], 
2 lentelè. Atrinktų straipsnių parametrų santrauka

\begin{tabular}{|c|c|c|c|c|c|c|c|c|}
\hline $\begin{array}{l}\text { Imties } \\
\text { tūris }\end{array}$ & Amžius & $\begin{array}{l}\text { Imties } \\
\text { tipas }\end{array}$ & \begin{tabular}{|c|} 
Imties \\
sudary- \\
mo prin- \\
cipas \\
\end{tabular} & $\begin{array}{c}\text { Gerovès / gyvenimo } \\
\text { kokybės matavimo } \\
\text { būdas }\end{array}$ & $\begin{array}{c}\text { Fizinės sveikatos } \\
\text { veiksniai }\end{array}$ & $\begin{array}{l}\text { Psichikos svei- } \\
\text { katos veiksniai }\end{array}$ & $\begin{array}{c}\text { Dau- } \\
\text { giamatè } \\
\text { analizè }\end{array}$ & $\begin{array}{l}\text { Nuo- } \\
\text { roda, } \\
\text { metai }\end{array}$ \\
\hline 62 & $\mathrm{~V}^{*}$ & Sv, mot & I & $\begin{array}{c}\text { EORTC QLQ-C30; } \\
\text { EORTC QLQ-Br23; } \\
\text { FACT-An }\end{array}$ & $\begin{array}{c}\text { Krūties vėžio opera- } \\
\text { cijos tipas }\end{array}$ & & - & 2005 [16] \\
\hline 121 & $V=66,63$ & $\begin{array}{c}\text { Sv; } \\
\text { L2b2m }\end{array}$ & $\mathrm{A} ; \mathrm{LTr}$ & WHOQOL-100 & $\begin{array}{l}\text { Ligos (Parkinsono) } \\
\text { forma ir eiga }\end{array}$ & & - & $2006[17]$ \\
\hline 294 & $\begin{array}{l}75-98 \\
\text { metų }\end{array}$ & $\mathrm{Bp}, \mathrm{vyr}$ & A; St; LTr & WHOQOF-BREF & $\begin{array}{c}\text { Šlapimo nelaikymo } \\
\text { faktas }\end{array}$ & & - & $2006[18]$ \\
\hline 393 & $\mathrm{~V}^{*}$ & $\mathrm{~Sv}$ & $\mathrm{I}+\mathrm{A}, \mathrm{LTr}$ & CLDQ & $\begin{array}{l}\text { Sirgimo kepenų } \\
\text { ciroze faktas, ligos } \\
\text { tipas, ligos sunku- } \\
\text { mas }\end{array}$ & & - & 2006 [19] \\
\hline 77 & $\begin{array}{c}32-72 \text { metų; } \\
\mathrm{V}=53,1\end{array}$ & $\begin{array}{c}\text { Sv, } \\
\text { L2b9mèn }\end{array}$ & $\mathrm{I}$ & $\begin{array}{l}\text { FACT-G; } \\
\text { FACT-An }\end{array}$ & $\begin{array}{l}\text { Krūties vėžio gy- } \\
\text { dymo tipas, laikas } \\
\text { po operacijos }\end{array}$ & & + & 2007 [20] \\
\hline $\begin{array}{l}191- \\
123\end{array}$ & $\mathrm{~V}=54,72$ & $\begin{array}{c}\mathrm{Sv} \\
\mathrm{L} 4 \mathrm{~b} 3 \mathrm{~m}\end{array}$ & I & SF-36 & $\begin{array}{l}\text { Ligos (reumatoidi- } \\
\text { nio artrito) eiga ir } \\
\text { klinikiniai veiksniai } \\
\text { (simptomai) }\end{array}$ & $\begin{array}{l}\text { Depresiškumas, } \\
\text { nerimastingu- } \\
\text { mas }\end{array}$ & - & 2008 [21] \\
\hline 494 & 55-74 metur & Bp, vyr & A; St; LTr & WHOQOL-Bref & $\begin{array}{c}\text { Šlapimo nelaikymo } \\
\text { faktas }\end{array}$ & & - & 2009 [22] \\
\hline 602 & $>60$ metur & $\mathrm{Bp}$ & $\mathrm{P}$ & $\begin{array}{c}\text { Klausimas, ar sveikata } \\
\text { veikia gyvenimo } \\
\text { kokybę } \\
\end{array}$ & $\begin{array}{c}\text { Nuomonè, ar } \\
\text { sveikata veikia } \\
\text { gyvenimo kokybę }\end{array}$ & & - & 2010 [23] \\
\hline 284 & $\mathrm{~V}=55,9$ & $\mathrm{~Sv}$ & $\mathrm{I}$ & EORTC QLQ-C30 & $\begin{array}{c}\text { Krūties vèžio sta- } \\
\text { dija, simptomai }\end{array}$ & & - & $2010[24]$ \\
\hline 127 & 65-85 metu & $\mathrm{BG}, \mathrm{mot}$ & $\mathrm{I}$ & $\begin{array}{l}\text { SF-36v2; } \\
\text { I-QOL }\end{array}$ & $\begin{array}{c}\text { Šlapimo nelaikymo } \\
\text { faktas }\end{array}$ & & - & 2011 [25] \\
\hline 486 & $\mathrm{~V}=69,36$ & Sv, vyr & $\mathrm{I}$ & EORTC QLQ-C30 & $\begin{array}{c}\text { Prostatos vèžio sir- } \\
\text { gimo trukmė, eiga ir } \\
\text { gydymo būdas }\end{array}$ & & + & 2012 [26] \\
\hline 6904 & $45-72$ metų & $\mathrm{Bp}$ & A, LTr, St & Vienas klausimas & & $\begin{array}{l}\text { Kognityvinis } \\
\text { funkcionavimas }\end{array}$ & - & 2012 [27] \\
\hline 560 & $V=57$ & $\mathrm{~Sv}$ & $\mathrm{I}$ & SF-36 & $\begin{array}{l}\text { Sergančiujų išemine } \\
\text { liga klinikinè būklè }\end{array}$ & $\begin{array}{c}\text { Depresija, } \\
\text { nerimas }\end{array}$ & + & 2013 [28] \\
\hline 6947 & $\begin{array}{c}\mathrm{V}=60,4 \\
\text { (moteru), } \\
\mathrm{V}=60,6 \\
\text { (vyrų) }\end{array}$ & $\mathrm{Bp}$ & A, St, LTr & Vienas klausimas & & $\begin{array}{l}\text { Depresijos } \\
\text { simptomai }\end{array}$ & - & 2014 [29] \\
\hline 855 & $\mathrm{~V}=58,6$ & $\begin{array}{c}\mathrm{Sv} \\
\mathrm{L} 5 \mathrm{~b} 2 \mathrm{~m}\end{array}$ & I & MLHFQ & $\begin{array}{c}\text { Išeminès ligos } \\
\text { ypatumai, laikas po } \\
\text { reabilitacijos }\end{array}$ & $\begin{array}{l}\text { Nerimas, } \\
\text { depresija }\end{array}$ & + & 2015 [30] \\
\hline 172 & $\begin{array}{l}\mathrm{V}=64,5 \\
(\text { vyrü), } \\
\mathrm{V}=63,5 \\
\text { (moterų) }\end{array}$ & BG & I & OAB-q & $\begin{array}{c}\text { Šlapimo nelaikymo } \\
\text { tipas }\end{array}$ & & - & 2016 [31] \\
\hline
\end{tabular}

Pastaba:

Amžius: $V$-vidurkis; $V^{*}$ - tikslus amžiaus vidurkis nenurodytas, bet kiti duomenys leidžia suprasti, kad jis didesnis už 50 .

Imties tipas: Sv-tiriamieji pasižymi specifiniais sveikatos ypatumais; L-longitudinis tyrimas, žymejjimo pavyzdys: L2b2m-longitudas, dvi bangos, du metai. Bp-bendra populiacija. vyr-vyrai. BG-besikreipiantys $i$ gydytoja. Mot-moterys.

Atrankos būdas: A-atsitiktine; LTr-Lietuvos regionas; St-stratifikuota; $P$-netikimybine patogioji

Gerovés ivertinimo instrumentai:

CLDQ - Chronišku kepenu ligu klausimynas [32] 
EORTC QLQ-Br23 - EORTC gyvenimo kokybès klausimyno krūties véžio modulis [33] EORTC QLQ-C30 - EORTC gyvenimo kokybès klausimynas C30 [33]

FACT-An - Funkcinio véžio terapijos jivertinimo anemijos skale [34]

FACT-G - Vėžio terapijos funkcinio ịvertinimo bendra skale. [35]

I-QOL - Gyvenimo kokybès klausimynas asmenims su šlapimo nelaikymu [36]

MLHFQ - Minesotos gyvenimo su širdies sutrikimais klausimynas [37]

OAB-q-Hiperaktyvios šlapimo pūslès klausimynas [38]

SF-36 - Medicininiu pasekmiu klausimynas - trumpoji forma [39].

WHOQOF-BREF - PSO gyvenimo kokybés klausimynas - sutrumpintas [40]

WHOQOL-100 - PSO gyvenimo kokybè-100 (WHOQOL) klausimynas [40]

vèlesnè krūties vėžio [24] ar kepenų cirozės [19] stadija siejosi su prastesne gerove. Ne vien sirgimas viena ar kita liga, bet ir ligos simptomų sunkumas taip pat siejasi su gerove. Ryškesni krūties vėžio simptomai (nuovargis, skausmas ir t.t.) siejosi su prastesne gerove [24], išeminès ligos sunkumas siejosi su žemesniu gerovès lygiu $[28,30]$. Analizuotų tyrimų rezultatai leidžia ižvelgti, kad skirtingos skirtingų ligų formos nevienodai veikia gerovę. Pavyzdžiui, sergančiujų skirtingomis kepenų cirozės formomis gyvenimo kokybè buvo panaši [19], tačiau sergantieji rigidine ir tremorinerigidine Parkinsono ligos formomis savo bendrą gyvenimo kokybę vertino blogiau, nei sergantieji tremorine ligos forma [17]. Gyvenimo kokybè taip pat skyrèsi priklausomai nuo šlapimo nelaikymo tipo [31]. Atliktos daugiamates analizès leidžia ǐžvelgti, kad gerovès ir sveikatos ryšiui gali būti svarbūs ir socialiniai - demografiniai $[26,31]$ ar asmenybès kintamieji $[28,30]$.

Penki $(31,3 \%)$ iš analizuotụ tyrimų kartu su gerovès vertinimu apėmè ir psichikos sveikatos veiksnius, dažniausiai buvo vertinami nerimas ir depresija [21, 28-30], nustatoma, kad nerimo ir depresijos didesni ịverčiai siejasi su žemesne gerove. Viename tyrime [27] analizuotas kognityvinis sergančių asmenų funkcionavimas, o tyrimo rezultatai leidžia teigti, kad prastesnis kognityvinis funkcionavimas siejasi su mažesne gerove.

Analizuojant rezultatus dažniausiai buvo taikoma vienmate statistika (koreliacijos arba grupių palyginimai), tik keturios studijos (25\%) naudojo ir daugiamates statistikos (daugialypès regresinès analizès, vienoje studijoje - mediacijos, tačiau sveikatos kintamieji ten buvo asmenybinių veiksnių ir gerovès ryšio mediatoriais) metodus, kai gerové buvo priklausomas kintamasis.

\section{Diskusija}

Realizuodami straipsnio tikslą ir bandydami atsakyti i ivvade išsikeltus klausimus, pirmiausia aptarsime rastų tyrimų rezultatus, tuomet - metodologinius tyrimų trūkumus, galiausiai - išryškejusias spragas atliekamų emipirinių tyrimų lauke.

Apibendrinant rastų tyrimų rezultatus, galima konstatuoti, kad tyrimai rodo, jog sirgimas viena ar kita liga (vèžiu, Parkinsono liga, išemine širdies liga, reumatoidiniu artritu, kepenų ciroze ar šlapimo nelaikymu) yra susijęs su žemesne gerove, kuri dažniausiai vertinama, tiriant su sveikata susijusią gyvenimo kokybę. Taip pat yra įrodymų, kad ligai progresuojant ir sunkejjant ligos simptomams, gerové prasteja. Prastesnè gerove siejasi ir su psichikos sveikatos problemomis. Šie apibendrinti rezultatai iš esmès atitinka anksčiau Lietuvoje ar kitose šalyse atliktų tyrimų rezultatus $[5,8,9]$. Psichikos sveikatos problemų sąsajos su mažesne gerove taip pat nustatomos ir kitų tyrimų $[9,41]$. Tačiau nepaisant gana aiškių ir neprieštaringų rezultatų, tyrimai turi nemažai metodologinių problemų, taip pat daug gerovès ir sveikatos sąsajų aspektų yra Lietuvoje netirti.

Pirmiausia, nemaža dalis analizuotų tyrimų grịsti santykinai nedidelemis imtimis. Kitas, jau didesnis trūkumas - imčių reprezentatyvumo stoka. Dominuoja vieno tipo sutrikimą turintys asmenys, dažnai tiriami vienos ar kelių institucijų pacientai. Tyrimai, kuriuose dalyvavo kad ir atsitiktinai atrinkti gyventojai, visvien neapémè visos Lietuvos, o tyre tik vieno regiono (Vilniaus arba Kauno) respondentus. Pasitaikantys longitudiniai tyrimai suteikia labai svarbios informacijos apie gerovès pokyčius sergant viena ar kita liga, tačiau jie įtraukè tik sergančius respondentus ir buvo santykinai trumpalaikiai ( 9 mènesiai - 3 metai). Dèl tyrimų imčių ribotumo mes neturime svarbių atsakymų ị visą eilę klausimų: kokia yra gerové, jei asmuo serga keliomis ligomis ir kokia yra šalutinių ligų reikšmé? Kaip iš viso atrodo vyresnio amžiaus asmenų bendras sveikatos ir gerovés profilis, sergant skirtingomis lètinemis ligomis? Kaip keičiasi gerovė po visiško pasveikimo arba lètinių ligų atveju - pasiekus optimalią ligos ir jos simptomų kontrolę? Kaip skiriasi sveikatos ir gerovés sąsaja, jei asmuo gyvena skirtingomis socioekonominėmis sąlygomis? Panašius klausimus būtų galima vardinti ir vardinti.

Antra, gerovei vertinti naudojama dažniausiai su sveikata susijusios gerovès skalès, dažnai kurtos sergantiesiems specifine liga. Tai labai svarbus informacijos šaltinis, siekiant suprasti, kaip konkreti liga veikia asmens gerovę. Tačiau drauge tokių instrumentų naudojimas neleidžia matyti platesnio paveikslo. Pavyzdžiui, iš esmès nieko nežinome apie vyresnio amžiaus asmenų psichologinès gerovès ir sveikatos sąsajas. Taip pat ligai specifinių instrumentų naudojimas neleidžia palyginti skirtingomis ligomis sergančių asmenų sveikatos rodiklių reikšmès jų gerovės lygiui.

Trečia, dauguma tyrimų apsiriboja vienmate statistine analize, o iš daugiamatès statistikos metodų taikyta iš esmès tik regresinè analizè. Tokių ribotų analizès procedūrų taikymas, neịtraukiant sudètingesnių dispersinès analizès metodų, mediacinès, moderacinès analizès ar modeliavimo struktūrinėmis lygtimis iš esmès neleidžia suprasti, kaip sveikatos būklès ir asmens savijautos ryšį veikia socialiniai, demogra- 
finiai, ekonominès padèties, gaunamų gydymo paslaugų ir Lietuvoje veikiančios sveikatos priežiūros sistemos ypatumu kintamieji. O tarpkultūriniai tyrimai $[7,9]$ rodo, kad būtent šie kintamieji gali būti svarbiausi, siekiant suprasti, kaip vyresnio amžiaus žmonèms, susiduriantiems su sveikatos pablogejjimu, padèti išsaugoti gerovę.

Atlikta sisteminè analizè rodo, kad Lietuvoje trūksta visus gyventojus reprezentuojančių, aprèpiančių ne vieną sveikatos būklę ir aplinkybes tyrimų, kurių duomenys būtų analizuojami pasitelkiant sudètingesnius statistinius metodus.

\section{Išvados}

1. Analizuoti tyrimai rodo, kad sirgimas viena ar kita liga (věžiu, Parkinsono liga, išemine širdies liga, reumatoidiniu artritu, kepenų ciroze ar šlapimo nelaikymu) yra susijęs su žemesne gerove. Taip pat yra ịrodymų, kad ligai progresuojant, gerové prastejja. Prastesnè gerovè siejasi ir su psichikos sveikatos problemomis.

2. Analizuoti tyrimai pasižymi metodologiniais trūkumais - tyrimų dalyvių imčių repezentatyvumo stoka, ribotais gerovès tyrimo instrumentais bei daugiamatès statistinès analizès ribotu taikymu.

3. Atlikta sisteminė analizè leidžia teigti, kad Lietuvoje trūksta tęstinių, gyventojų struktūrą reprezentuojančių, lyginančių skirtingas sveikatos būkles skirtingomis gyvenimo aplinkybėmis, taikančių šiuolaikinius daugiamatès statistikos metodus, gerovès tyrimų.

Tyrima finansavo Lietuvos mokslo taryba, sutarties $\mathrm{Nr}$. MIP-010/2015.

\section{Literatūra}

1. Aristotelis. Nikomacho etika. Mintis, Vilnius, 1990.

2. Hallberg LRM, Ringdahl A, Holmes A, Carver C. Psychological general well-being (quality of life) in patients with cochlear implants: Importance of social environment and age. International Journal of Audiology 2005; 44:706-711.

https://doi.org/10.1080/14992020500266852

3. Fenge LA, Hean A, Worswick L, Wilkinson C, Fearnley S, Ersser S. The impact of the economic recession on well-being and quality of life of older people. Health and Social Care in the Community 2012;20(6): 617-624.

https://doi.org/10.1111/j.1365-2524.2012.01077.x

4. Krutulienè S. Gyvenimo kokybė: sąvokos apibrèžimas ir santykis su gero gyvenimo terminais. Kultūra ir visuomené, 2012;3(2):117-130.

5. Bagdonas A., Kairys A., Liniauskaitė A., Pakalniškienė V. Lietuvos gyventojų psichologinè gerovè ir jos veiksniai. VU leidykla, Vilnius, 2013.

6. Stiel S, Kues K, Krumm N, Radbruch L, Elsner F. Assessment of quality of life in patients receiving palliative care: comparison of measurement tools and single item on subjective well-being. Journal of Palliative Medicine 2011;14(5):599-606.

https://doi.org/10.1089/jpm.2010.0473

7. Steptoe A, Deaton A, Wilson W, Stone AA. Psychological wellbeing, health and ageing. Lancet 2015;385(9968):640-648. https://doi.org/10.1016/S0140-6736(13)61489-0

8. Baernholdt M, Hinton I, Yan G, Rose K, Mattos M. Factors associated with quality of life in older adults in the United States. Qual Life Res 2012;21(3):527-534.

https://doi.org/10.1007/s11136-011-9954-Z

9. Netuveli G, Wiggins RD, Hildon Z, Montgomery SM, Blane D. Quality of life at older ages: evidence from the English longitudinal study of ageing (wave 1). J Epidemiol Community Health 2006;60:357-363.

https://doi.org/10.1136/jech.2005.040071

10. Dolan P, Peasgood T, White M. Do we really know what makes us happy? A review of the economic literature on the factors associated with subjective well-being. Journal of Economic Psychology 2008;29:94-122.

https://doi.org/10.1016/j.joep.2007.09.001

11. Binder M, Coad A. An examination of the dynamics of wellbeing and life events using vector autoregressions. Journal of Economic Behavior \& Organization 2010;7:352-371.

https://doi.org/10.1016/j.jebo.2010.06.006

12. Ornstein SM, Nietert PJ, Jenkins RG, Litvin CB. The prevalence of chronic diseases and multimorbidity in primary care practice: A PPRNet report. JABFM 2013;26(5):518-524.

https://doi.org/10.3122/jabfm.2013.05.130012

13. Netuveli G, Blane, D. Quality of life in older ages. British Medical Bulletin 2008;85:113-126.

https://doi.org/10.1093/bmb/ldn003

14. Litwn H. Social networks and well-being: a comparison of older people in mediterranean and non-mediterranean countries. Journal of Gerontology: Social Sciences 2009;65B(5):599-608. https://doi.org/10.1093/geronb/gbp104

15. Marmot M, Bobak M. International comparators and poverty and health in Europe. BMJ 2000;321:1124-8. https://doi.org/10.1136/bmj.321.7269.1124

16. Bulotienè G, Ostapenko V, Vesèliunas J. Influence of social factors on the quality of life after breast cancer surgical treatment. Acta Medica Lituanica 2005;12(2):79-83.

17. Valeikienė V., Juozulynas A. Gyvenimo kokybė sergant Parkinsono liga. Gerontologija, 2006;7(2):78-87.

18. Mereckas G., Alekna V. Šlapimo nelaikančių vyrų gyvenimo kokybè. Gerontologija, 2006;7(4):201-207.

19. Sumskiene J, Sumskas L, Petrauskas D, Kupcinskas L. Disease-specific health-related quality of life and its determinants in liver cirrhosis patients in Lithuania. World J Gastroenterol 2006;12(48):7792-7797.

https://doi.org/10.3748/wjg.v12.i48.7792

20. Bulotiene G, Veseliunas J, Ostapenko V. Quality of life of Li- 
thuanian women with early stage breast cancer. BMC Public Health 2007;7:124.

https://doi.org/10.1186/1471-2458-7-124

21. Stropuvienė S., Dadonienė J., Rugienė R., Venalis A. Trejų metų gyvenimo kokybès pokyčių ịvertinimas pacientams, sergantiems reumatoidiniu artritu. Gerontologija, 2008;9(4):219-228.

22. Mereckas G., Alekna V., Čeremnych E. Šlapimo nelaikymo sąlygoti gyvenimo kokybès aspektai. Gerontologija, 2009;10(1):23-28.

23. Vaznonienè G. Subjektyvios pagyvenusių žmonių gyvenimo kokybės socialiniai ekonominiai veiksniai. Sociologija. Mintis ir veiksmas, 2010;2(27):186-204.

24. Ivanauskienė R, Kregždytė R, Padaiga Ž. Evaluation of healthrelated quality of life in patients with breast cancer. Medicina 2010;46(5):351-359.

25. Jievaltienė G., Lesauskaitė V., Šmigelskas K., Kučikienė O. Pagyvenusių moterų šlapimo nelaikymas ir gyvenimo kokybė. Gerontologija, 2011;12(2):75-81.

26. Mickevičiene A, Vanagas G, Ulys A, Jievaltas M, Smailytė G, Padaiga Ž. Factors affecting health-related quality of life in prostate cancer patients. Scandinavian Journal of Urology and Nephrology 2012;46:180-187. https://doi.org/10.3109/00365599.2012.661765

27. Tamosiunas A, Baceviciene M, Reklaitiene R, Radisauskas R, Jureniene K, Azaraviciene A, Luksiene D, Malinauskiene V, Daugeliene E, Sapranaviciute-Zabazlajeva L. Cardiovascular risk factors and cognitive function in middle aged and elderly Lithuanian urban population: results from the HAPIEE study. BMC Neurology 2012;12:149.

https://doi.org/10.1186/1471-2377-12-149

28. Staniūtė M., Brožaitienė J., Bunevičius R. Psichoemocinių veiksnių sąsajos su išemine širdies liga sergančių asmenų gyvenimo kokybe. Visuomenės sveikata, 2013; Priedas 1:129-136.

29. Sapranaviciute-Zabazlajeva L, Reklaitiene R, Tamosiunas A, Baceviciene M, Virviciute D, Peasey A. Correlates of depressive symptoms in urban middle-aged and elderly Lithuanians. Soc Psychiatry Psychiatr Epidemiol 2014;49:1199-1207. https://doi.org/10.1007/s00127-014-0833-0

30. Staniute M, Brozaitiene J, Burkauskas J, Kazukauskiene N, Mickuviene N, Bunevicius R. Type D personality, mental distress, social support and health-related quality of life in coronary artery disease patients with heart failure: a longitudinal observational study. Health and Quality of Life Outcomes 2015;13:1. https://doi.org/10.1186/s12955-014-0204-2

31. Aniulienė R, Aniulis P, Steibliene V. Risk factors and types of urinary incontinence among middle-aged and older male and female primary care patients in Kaunas region of Lithuania: cross sectional study. Urology Journal 2016;13(01):2552-2561.

32. Younossi Z M, Guyatt G, Kiwi M, Boparai N, King D. Development of a disease specific questionnaire to measure health related quality of life in patients with chronic liver disease.
Gut. 1999;45:295-300.

https://doi.org/10.1136/gut.45.2.295

33. EORTC. EORTC QLQ-C30 Scoring Manual. EORTC, Brusels, 2001.

34. Cella D. The Functional Assessment of Cancer Therapy-Anemia (FACT-An) Scale: a new tool for the assessment of outcomes in cancer anemia and fatigue. Semin Hematol 1997;34(3 Suppl 2):13-9.

35. Cella D, Tulsky D, Gray G, Sarafian B, Linn E, Bonomi A, Silberman M, Yellen S, Winicour P, Brannon J, Eckberg K, Lloyd S, Purl S, Blendowski C, Goodman M, Barnicle M, Stewart I, McHale M, Bonomi P, Kaplan E, Taylor S, Thomas C, Harris J. The Functional assessment of cancer therapy scale: development and validation of the general measure. Journal of Clinical Oncology 1993;11(3):570-579.

https://doi.org/10.1200/JCO.1993.11.3.570

36. Patrick DL, Martin ML, Bushnell DM, Yalcin I, Wagner TH, Buesching DP. Quality of life of women with urinary incontinence: further development of the Incontinence quality of life instrument (I-QOL). Urology 1999;53(1):71-76.

https:/doi.org/10.1016/S0090-4295(98)00454-3

37. Bilbao A, Escobar A, García-Perez L, Navarro G, Quirós R. The Minnesota living with heart failure questionnaire: comparison of different factor structures. Health and Quality of Life Outcomes 2016;14:23.

https://doi.org/10.1186/s12955-016-0425-7

38. Coyne K, Revicki D, Hunt T, Corey R, Stewart W, Bentkover J, Kurth H, Abrams P. Psychometric validation of an overactive bladder symptom and health-related quality of life questionnaire: The OAB-q. Quality of Life Research 2002;11:563-574. https://doi.org/10.1023/A:1016370925601

39. Ware JE, Sherbourne CD. The MOS 36-item short-form health survey (sf-36): I. Conceptual framework and item selection. Medical Care 1992;30(6):473-483.

https://doi.org/10.1097/00005650-199206000-00002

40. The World Health Organization. Measuring quality of life the World Health Organization Quality of life instruments (the WHOQOL-100 and the WHOQOL-BREF). WHO, 1997.

41. Hays RD, Wells KB, Sherbourne CD, Rogers W, Spritzer K. Functioning and well-being outcomes of patients with depression compared with chronic general medical illnesses. Arch Gen Psychiatry 1995;52:11-19.

https://doi.org/10.1001/archpsyc.1995.03950130011002

\section{RELATIONSHIPS BETWEEN WELL-BEING AND HEALTH AMONG OLDER ADULTS IN LITHUANIA: SYSTEMIC REVIEW}

A. Kairys, A. Bagdonas, O. Zamalijeva view.

Key words: health, well-being, quality of life, systematic re-

Summary

Both, empirical studies and theoretical assumptions suggest 
that well-being is a complex, multi-dimensional construct. Research indicates that the level of well-being is determined by a variety of variables and the aspects of individual's health are often proposed to be the essential ones. Analysis of health and wellbeing interrelations is usually accompanied by numerous obstacles due to influences of third variables that may by altering these relations and are difficult to control for. To this day it is still unclear how well-being is changing during normal ageing and what role could health play in this process. Another important fact is that the link between health and well-being may depend on culture or be country specific. Therefore, it is necessary to examine what links are found between health and well-being in older Lithuanian population. Hence, the aim of this study is to analyze the research of well-being and health associations conducted in Lithuanian population of older adults using systemic review approach. In order to address this purpose, electronic literature searches were carried out in PsychInfo, Academic Search Complete, MEDLINE, SocINDEX with Full Text, ERIC, Science direct and Lituanistika databases. The searches yielded 897 published studies. Based on the title 274 studies seemed potentially suitable and were selected for further examination. After abstracts and full texts were screened, a total of 16 papers met all the inclusion criteria and were included in this review. Analyzed studies show that having a chronic disease in later life (cancer, Parkinson's disease, coronary artery disease, rheumatoid arthritis, cirrhosis or urinary incontinence) is indicative of lower levels of well-being. There is also evidence that with the progression of the disease, well-being tends to decrease even more. Decreased well-being outcomes are also associated with mental health issues. Studies analyzed in this review have various methodological issues - nationally non-representative study samples, limited well-being assessment tools and limited utilization of multivariante statistical methods. On the whole, results of systemic review indicate that research of relationships between health and well-being in Lithuania is lacking longitudinal and representative population-based data that would compare various health conditions under different living circumstances while using modern multivariate statistics.

Correspondence to: antanas.kairys@fsf.vu.lt

Gauta 2017-06-27 